\title{
Искусство Выговской пустыни К вопросу детерминирования феномена старообрядчества в культуре Русского Севера
}

Аннотация: Предметом исследования является изобразительное искусство Выговской пустыни. Объект исследования - феномен старообрядчества в культуре Русского Севера. В ходе работы особое внимание уделено выявлению концептов устойчивости и модернизации традиций в старообрядческом искусстве Севера. Доказано, что при всей противоречивости, воздействие староверческой среды на культуру Северной Руси носило позитивный характер, в частности, в расширении ареала художественных традиций края. Исследованы факторы, способствующие распространению северного искусства за пределами окраинных земель: на Урале, в Сибири, Поволжье, Центральной России. В данной статье необходимо применение комплексного междисциплинарного подхода. В качестве специальной методологии исследования избран целостный подход, который базируется на идеях системного анализа. При работе над конкретными научными задачами автор опирался на следующие методы исследования:1. искусствоведческий анализ произведений, что важно для понимания образных, идейных решений, для выявления их художественного языка; 2. в вопросах атрибуции значимы компаративистский и технико-технологический методы, позволяющие выявить типологию и специфику конкретного памятника. 3. историко-этнографический метод способствует изучению образцов старообрядческого творчества и выявления в них общерусских традиций, символических смыслов. Основными выводами проведенного исследования являются: 1. обоснование значимости Выговской пустыни как художественного центра Русского Севера; 2. детерминирование исключительности феномена старообрядчества в историко-культурной и религиозно-философской среде, как Севера, так и далеко за его пределами; 3. выявление значимой роли “ревнителей древлего благочестия" в распространении северных традиций в большинстве регионов России.

Ключевые слова: Старообрядцы, Выг, Русский Север, искусство, живописные иконы, меднолитые иконы, орнаменты, векторность, Урал, Поволжье.

Review: The subject of the research is the fine art of the Vyg Monastery. The object of the research is the phenomenon of the old believers in the culture of the Russian North. During the research particular attention was paid to identifying the concepts of sustainability and modernization of the old believer traditions in the art of the North. It is proved that for all the controversy, the impact of the old believers on the culture of Northern Russia was positive, in particular, it extended the range of artistic traditions of the region. In her research Skorobogacheva has studied the factors contributing to the spread of Northern art beyond the marginal land: in the Urals, Siberia, the Volga region and Central Russia. In this research it was necessary to use an integrated and multidisciplinary approach. Special research methodology involved the holistic approach, which is based on the ideas of system analysis. When working on specific research tasks, the author relied on the following methods of research: 1. art criticism analysis of works that it is important to understand figurative, ideological solutions and to identify their artistic language; 2. in matters of attribution comparative technical and technological methods are important because they allow to describe the classification and specifics of a particular monument. 3. historical-ethnographic method which encourages the research of old believers ' art samples and analysis of Russian traditions and symbolic meanings therein. The main results of the research are: 1. proof of the the importance of the Vyg Monastery as an artistic centre of the Russian North; 2. determination of the uniqueness of the phenomenon of the old believers in the historicalcultural and religious-philosophical environment, both in the North and far beyond its borders; 3. description of the significant role of the old believers in the distribution of the Northern traditions in most regions of Russia.

Keywords: Ural, vectorvest, old believers, Vyg, Russian North, art, painted icons, cast copper icons, ornaments, Volga Region. 
A реал Русского Севера - это целостное духовное пространство, содержащее в себе основы национального мировоззрения во всем многообразии их проявлений. Обращение к исконным вневременным духовным истокам ведет к укреплению самосознания народа, сплочению нации, государства, что исключительно важно в современном мире. По заключению E.М. Примакова, «без России трудно, если вообще возможно, противодействовать вызовам и угрозам человечеству в XXI веке» [1, с. 52]. Самоидентификация народа невозможна без укрепления национальной культуры, значимой в мировом масштабе, о чем В.М. Васнецов писал: «Мы тогда только внесем свою лепту в сокровищницу всемирного искусства.., когда с возможными для нас совершенством и полнотой...сумеем в своем истинно национальном отразить вечное, непреходящее» [2, с. 154].

Искусство северного края подобно горящей свече, озаряющей «вечное, непроходящее» отечественного творчества. Эта свеча с великой верой вдохновенно зажжена в старинных бревенчатых храмах, явлена в древних сказочно-былинных градах, в «избяной литургии», в сохраненных и утраченных обителях, в иконах - «умозрениях в красках». Русский Север - это «премудроверхие» величественномогучие храмы Кижей, неудержимо поднявшиеся средь необъятных просторов. Городалегенды, «стоящие на веках» - живописная, резная, радушная Вологда; Великий Устюг, «кладезю» народной памяти, с драгоценной россыпью древних церквей и бревенчатых домов, с деревянными настилами улиц. Окраинные земли - это бесконечность сурово-темных лесов, края «непуганных птиц», где за орнаментом еловых лап покажется вдруг замшелый, сизый от бессчетных дождей и снегов охотничий лабаз. Это и поморские кресты, непреклонно и гордо стоящие средь седых валунов, мощно устремленные ввысь, наперекор всему. Так оживает призрачно-реальный мир древней северной Руси, ибо свеча духовного горения, сохраненного национального искусства, не гасла здесь со стародавних времен, несмотря на эпохи смут, лихолетий, не должна погаснуть ныне.

В наши дни Север и его «корона»-Арктика - открывают России новые и новые богатства. Ведутся исследования края в предельно широком научном спектре. Но до настоящего времени оставалась совершенно неисследованной научная проблема векторности старообрядческого искусства Русского Севера. Автор ставит перед собой задачу на основе изучения исторических фактов и художественных произведений старообрядческого искусства выявить и доказать значимость векторности в возникновении и развитии самобытного искусства староверов. Оно, взращенное на почве древних общерусских традиций, раскрылось особым диковинным цветком, скрытым среди северных топей, в глуши дремучих лесов, который погубить не смогли ни реформы никониан, ни изменчивость художественных вкусов, ни всевластное время.

Северная Русь детерминирует тот мощный духовный стержень, который во многом позволяет сохранять русское национальное искусство со стародавних времен и поныне. Однако данный вопрос крайне мало освещен в научных трудах. За последние десятилетия искусствоведческая наука, в том числе в вопросах изучения искусства Севера, значительно продвинулась вперед, но, вместе с тем, исследование культуры старообрядцев на стыке научных дисциплин не получило должного научного рассмотрения.

Почти не освоенный материал представляет аргументированная оценка Русского Севера в эволюционном процессе становления отечественного искусства. За пределами теоретического изучения ныне находятся не только ряд промыслов и памятники, созданные под превалирующим северным влиянием, в том числе произведения Выговской старообрядческой пустыни, но в целом осмысление староверческого искусства Русского Севера и его духовных устоев в контексте становления самобытности русской национальной культуры.

По словам Л.Н. Гончаровой: «Консервативность и устойчивость крестьянского уклада на Севере способствовали созданию здесь своеобразного заповедника памятников материальной культуры...» [3, с. 3]. В данном контексте еще более существенно замечание академика РАН Б.А. Рыбакова, утверждавшего: «Русский Север, до сих пор [до XVIII в. - E.C.] лишь хранивший и укрывавший культурные богатства, полученные с Юга, стал как бы отдавать... в целости то, что в центре давно было забыто» [3, с. 3].

«Консервативность» старообрядческой среды соответствует самобытности искусства окраинных земель. Даже наиболее крайнее следование традиции последователями Авва- 
кума, порой принимающее эксцентрические, драматические, трагические формы, как самосожжения и запощевания, все же осознанно. Оно основано на идее сохранения древних устоев и выражения протеста против церковных нововведений, т. е. против конкретных исторических событий и личностей, а именно против реформы 1651 г., позиции царя Алексея Михайловича и Патриарха Никона, олицетворявшего антихриста для староверов. При этом самосожжение воспринималось ими как духовное очищение, а принятие «веры антихристовой» как скверна.

Об актуальности изучения феномена старообрядчества и векторности его культуры свидетельствует заключение М. В. Сурова: «Большинство дореволюционных работ, посвященных пресловутому «русскому расколу», написано с позиции официальной церкви и потому не могут претендовать на максимальную объективность. То же можно сказать и о трудах советских ученых, рассматривающих старообрядчество с атеистической точки зрения. К сожалению, не дают полной картины и творения самих «раскольников»» [4, с. 157].

Со второй половины XVII в. на Русском Севере формируются центры старообрядчества. Один из крупнейших и наиболее значимых в сфере культуры среди них - Выговская старообрядческая пустынь, столица северного старообрядчества, центр культуры и научной мысли «ревнителей древлего благочестия», не имеющий аналогов. На реке Выг, близ Онежского озера, в Обонежской пятине Олонецкого уезда, староверами в 1694 г. была основана Выговская обитель (Выгорецкая пустынь, Выговское общежительство, Выг) одно из крупнейших религиозно-культурных сосредоточий последователей Аввакума не только Севера, но и всего государства, сыгравшее видную роль в развитии культуры края XVIII - начала XIX столетия.

В данный период роль старообрядцев в сохранении стародавнего искусства была попрежнему велика. Их непризнание царской властью и официальной церковью оставалось. Петр I усилил борьбу с расколом, видя в его приверженцах «лютых неприятелей Государству и государю непрестанно замышляющих» [5, с. 67]. С не меньшей непреклонностью отвечали ему староверы, называя царя антихристом. Образ царя-антихриста немаловажен в их эсхатологических сочинениях, прежде всего в учении бегунов (странников). Однако известны случаи и терпимого отношения к ним императора. В 1702 г., проезжая с войском по «осударевой дороге», проходящей от Нюхчи до Повенца, Петр I не подверг старообрядцев притеснениям, но сказал: «Пускай живут» и «проехал смирно» [6, с. 107]. Сами раскольники ждали расправы, готовились пострадать за веру. Приемники Петра, прежде всего Екатерина Великая, относились к ним довольно терпимо. Однако противоречия все более обострялись в самой старообрядческой среде. Со второй четверти XVIII в. усилилось разделение на согласия, каждое из которых считало свое учение единственно верным, каждое из которых меняло древние традиции, в том числе искусство. Следовательно, некоторая степень модернизации традиций также свойственна староверам.

B XVIII в. постепенно внедрялись новшества в северную культуру, в частности, осуществлялся процесс претворения столичных барочных приемов. Необходимо рассмотреть роль «ревнителей древлего благочестия» Выга в данном процессе, выявить сочетание новаторства и «консервативности» в их искусстве, устойчивости и модернизации традиций, что позволит сделать заключение об основных тенденциях их среды и роли векторности в сохранении и распространении стародавних устоев.

В XVIII в. успешно развивается «скитское» письмо на Выге, в Устюге, Сольвычегодске и других центрах, следующих канонам XVI столетия. Поддерживаются и традиции XVII столетия, среди них - манера Федора Зубова (Евтихиева, Усольца), одного из известнейших северных иконописцев, работавшего в Москве, Ярославле, что подтверждает значимость векторности в культуре староверов, в данном случае адаптации в их среде искусства, признанного в столице.

У последователей Аввакума та или иная иконография нередко получала новые оттенки звучания. Широкое распространение приобрели изводы «Огненное восхождение Ильи Пророка». Обращение к образу св. Ильи иносказательно говорило о гарях (самосожжениях), которым подвергали себя приверженцы стародавних канонов в ответ на требования Никона и других поборников новой веры. «Ревнители древлего благочестия» понимали огонь как символ очищения и спасения. Так в 1670-х гг. вопрос о праве на самосожжение особенно обострился и не считался окончательно решенным [7, с. 8]. Неоднозначно отношение к крайним проявлениям «консерва- 
тизма» старообрядцев и в наши дни. Но, вместе с тем, не может не вызывать уважения их столь явная бескомпромиссность, пламенная убежденность в своей правоте и готовность стоять до конца за веру и ее каноны.

Таким образом, в исследовании впервые сделано заключение, что к старообрядческому искусству в некоторой степени приложимы термины и устойчивости, и модернизации традиций, а также определенная антиномичность сочетания данных концептов. Интенция «ревнителей древлего благочестия» сохранить традиции приводит в реалиях борьбы с расколом не только к их модернизации, но и к уничтожению - гарям, запощеваниям, разгромам староверческих монастырей, молелен, скитов, селений. Так, следование традиции, принимающее крайние, непримиримые, формы нивелирует данное стремление, губит традицию. Отсюда можно сделать вывод, распространяющийся не только на староверческое, но на традиционное искусство в целом. Его сохранение невозможно без поступательного, эволюционного движения. Следовательно, некоторая степень модернизации необходима и неизбежна даже для предельно «консервативного» искусства, в том числе для народного, коллективного, каким является искусство Русского Севера, в том числе искусство старообрядцев.

В иконописи «ревнителей древлего благочестия» образа поморского согласия отличаются характерными атрибуционными признаками. Здесь следовали наставлениям Андрея Денисова, первого настоятеля Выговского монастыря, его «Поморским ответам», где осуждалось изменение написания святых икон, обосновывалась каноничность двоеперстия, что подробно рассматривает Е.М. Юхименко [8, 9]. В происхождении поморских икон важно подчеркнуть значение векторности, а именно заимствование и претворение черт нескольких иконописных направлений, в том числе Новгорода Великого и северных писем. Об этом позволяют судить их художественные признаки. Согласно исследованию С.Н. Павлова [10, с. 110], типичен белесый оттенок округлых ликов, который достигался при использовании сильно разбеленной охры. Обязательны охристые поля поморских икон, как правило, с двойной обводкой (бордовой и зеленой). Им свойственно также отсутствие оживок, золотопробельное письмо в написании одежд.
Один из характерных промыслов Выга, литье медных икон, развивался в соответствии с требованиями духовной жизни XVIII в., вбирая традиции разных регионов. Как писал неизвестный автор «Послания об антихристе и тайном царстве его», а также «священнодиакон соловецкий Игнатий» - автор «Книги о титле на кресте Христове», в 1660-е гг. лили кресты с «голубками», то есть с изображением в верхней части креста над Распятием благословляющего Саваофа, а под ним Святого Духа в виде голубя [7, с. 49]. Этот тип крестов с надписью «І. Н. Ц. И.» стал общепринятым у староверов-поповцев: беглопоповцев, происходящих от них часовенных, австрийского или белокриницкого согласия. Однако, как правило, староверы не признавали такой аббревиатуры и ее религиозного смысла, а использовали другую: «ІС ХС ЦРЬ СЛВЫ».

B XVIII- XIX вв. производство меднолитых икон и крестов на Севере не снижалось, причем наряду с примерами грубой работы создавались достаточно высокохудожественные образцы. В 1719 г. была основана медница Выговской пустыни, и уже к середине XVIII в. ее иконы приобрели широкую известность и в Поморье, и по всему Северу среди старообрядческих конфессий, получили распространение в различных регионах России не только у старообрядцев, но и в православной среде, что также позволяет конкретизировать векторность старообрядческой культуры северного края.

По заключению Л.Н. Савиной, «достаточно сложен на сегодняшний день вопрос о типологии медного культового литья вообще и в XIX - начале XX в. в частности. В 1869 году И. Голышев писал: “Иконы медныя разделяются на 4 категории: Загарския (Гуслицкия), Никологарския (Никологорского погоста), Старинныя или Поморския (для раскольников Поморской секты) и Новыя. Новыя предназначаются для православных, а Старинныя - для раскольников, которые льются с особыми для них рисунками"» [11, с. 51].

По копии исходной формы Выга складни могли отливать в различных районах Русского Севера, в других центрах медного литья, например, в Гуслицах (под Москвой) или в самой Москве и для староверов, и для православных [11, с. 187]. Произведения поморской пластики стали образцом для московских «медных заведений», выполнявших заказы Преображенского кладбища, духовного и культурного центра старообрядцев-федо- 
сеевцев с 1771 г. Для многочисленных общин здесь отливали кресты, иконы, а также печатали книги, писали иконные образы. Особенно известны складни Выговской пустыни: Двунадесятые праздники; Деисус трехфигурный, большой и малый; композиция Деисуса, включающая девять фигур, в том числе Зосиму и Савватия Соловецких. Трактовка сюжетов соответствовала принятой иконографии. К чертам, свойственным искусству староверов, относится выбор сюжетов - Тихвинская икона Божьей Матери и Богоматерь Знамение. Им поклонялись прежде всего на Русском Севере, как и местночтимым святым: Зосиме и Савватию Соловецким, Сергию и Герману Валаамским, Кириллу Новоезерскому, Прокопию Устюжскому и другим. Показательно, например, что в состав меднолитого складня-триптиха Выга были включены Богоматерь Тихвинская, Спас Нерукотворный, Св. Сергий и св. Герман Валаамские. Таким образом, широкое распространение выговских меднолитых икон в России является одним из свидетельств значимости влияния старообрядческих северных традиций.

С другой стороны, в выговских художественных произведениях довольно активно адаптированы влияния из вне. Так, медному литью, традиционному крестьянскому искусству, также присуще воздействие барокко. На Выге создавались формы для меднолитых икон, где поля были затканы орнаментом, напоминающим о барочных мотивах и «поморском пошибе». Особенной известностью пользовались иконы с изображением на полях святых в круглых медальонах в обрамлении растительного орнамента. Сюжет средника менялся: «Спас Благое Молчание», «Благовещение», «Николай Чудотворец», но сохранялось решение их обрамлений. В середине XVIII в. был выработан характерный художественный почерк выговских икон: тонкий литой рельеф, применение гравировки, серебрения, золочения, оформление оборота орнаментом, напоминающим книжную заставку старопечатных изданий и гравированных листов второй половины XVII в. Ни в построении композиций, ни в трактовке фигур меднолитых икон не сказывалось прямое воздействие барокко, отзвук стиля звучал только в орнаментах. Неукоснительное следование религиозным канонам в искусстве Выга оставалось главным, что свидетельствует о превалирующей традиционности, архетипичности старообрядческого искусства.
Итак, меднолитой промысел характерен для среды «ревнителей древлего благочестия» Русского Севера. Наиболее ранние образцы относятся к XV в. Основой их иконографии служили живописные иконы, также резные по дереву и кости. В качестве исходной формы использовали обычно земляную и глиняную, иногда древесный гриб. До мельчайших подробностей техника и технология производства меднолитых икон описана в рукописном «Указе о медном мастерстве», хранящемся в Государственной Публичной библиотеке им. М.Е. Салтыкова-Щедрина в Санкт-Петербурге. В частности, в данном тексте говорится: «Первое подобает начати землю как угодно плавить в сосуде... Возьми верхнюю половину опоки да положи на доску да землю набей туго. Да ножем срежь гладко да тут покладай что намерено печатать. Ежели створы или распятие и кресты то правыми сторонами вниз а левыми вверх...» [12, с. 125]. Можно предположить, что такое руководство было весьма востребовано, поскольку едва ли не в каждом старообрядческом северном селении местные мастера отливали иконы, что показывает, насколько искусство неотрывно было соединено не только с обрядами, но и с повседневной жизнью старообрядцев.

По указу властей, мастеров-староверов нередко подвергали гонениям, изымали иконы. Меднолитые образа легче, чем живописные было спрятать, проще взять с собой в странствия. Древний промысел продолжался, несокрушимая преданность последоватлей протопопа Аввакума древним духовным корням снова и снова оказывалась сильнее официальных препон, запретов, гонений. Среди меднолитых икон Поморья особенно почитали по всей русской земле триптихи, образы Николы Чудотворца и Ильи Пророка, а также сложные по композиции пятистворчатые складни с изображением «Двунадесятых праздников». Также распространена в литье такая иконография, как «Деисус», «Двунадесятые праздники», «Распятие», «Ветхозаветная Троица», «Никола Чудотворец», «Св. Пантелеймон». C меднолитыми иконами, крестами, плакетками, складнями староверы не расставались, передавали их из поколения в поколение как драгоценность, берегли как семейную реликвию.

Воздействие барокко в меднолитых образах наиболее ощутимо в широком использовании поморского орнамента - яркого элемента искусства XVIII в., широко известного в России. 
Основой его сложения стали значительно измененные на Севере столичные мотивы последней четверти XVII столетия, искусства, процветавшего при царском дворе, прежде всего, орнаментальные листы, гравированные на меди и предназначенные для титулов рукописных книг. Единство композиций, встречающихся в различных произведениях, в разных видах живописи, в графике, объясняется отчасти спецификой деятельности старообрядческих мастеров. Они работали в нескольких сферах творчества: писали иконы, выполняли книжные заставки, а также расписывали дуги, сани, наличники домов, могли делать прориси для меднолитых икон, крестов, складней [13].

При этом в орнаментальном искусстве староверов немаловажны древние символы, как Мировое древо, Сирин, Процветший крест. На примере мотивов Сирина и Мирового Древа (Древа жизни), поражающих многообразием вариаций и тонкостью исполнения, следует заключить, что многие сюжеты, мотивы в росписи, вышивке, литье староверческого Севера, основанные на синтезе традиций культур Древнего мира, приобретали национальное звучание. Нередко они частично утрачивали прежнюю символику. Сохраняя внешнюю форму, такие мотивы получали новое религиозно-философское содержание, столь глубоко воспринятое в народной среде, в крестьянстве Русского Севера, словно соединенные с генетической памятью, глубинными духовными основами мирочувствования. Данная черта прослеживается во всем многообразии северного искусства, свидетельствует, что именно сохранение национальных основ при обязательной векторности определяет самобытность искусства края, многокрасочное богатство его вариаций.

Искусство книги также являлось важной самобытной составляющей старообрядческой культуры. Именно в этой области на Выге создавали высокохудожественные образцы, обладающие сходными художественными характеристиками и с живописными, и с меднолитыми иконами, и с орнаментальным декором всего многообразия староверческого декоративно-прикладного искусства. Уже в первое время существования Выговской пустыни была осознана необходимость в собственных книгах и иконах. «Поморский пошиб», очень устойчивый по своей трактовке, с XVIII в. широко известен, переработан в Каргополе, Пудожском, Медвежьегорском, Повенецком, За- онежском центрах, да и по всей Руси, поскольку выговские насельники снабжали книгами и иконами многие поморские (беспоповские) общины, что вновь со всей очевидностью позволяет акцентировать векторность северной старообрядческой культуры.

Западноевропейские влияния также сказывались в среде «ревнителей древлего благочестия», о чем свидетельствует тот факт, что наставник монастыря Андрей Борисов под влиянием западных идей стремился организовать на Выге Академию. Исполнению его замысла помешали сильные пожары 1787 г. Известностью в Выгореции пользовались риторические произведения, основу которых составляют труды западноевропейских средневековых авторов, прежде всего Раймонда Луллия - испанского философа, теолога XIII- начала XIV вв., мировоззрение которого сложилось под влиянием францисканства и Августина. Мир для Луллия - символ Бога, в каждой вещи отражающий божественные «совершенства». Для познания действия Бога в мире Луллием были разработаны методы логических операций. Одна из главные его работ - «Великая наука» - представляет собой сплав философии, риторики, этики.

На Выге, а также в других старообрядческих общинах, знали его «Луллианскую риторику» и «Книгу философскую». Западноевропейские взгляды во многом перерабатывались в Выгореции, переосмысливалась их специфика, находила отклик на русской почве. Насельники здесь были знакомы также с «Риторикой» Софрония Лихуда, «Риторикой» Феофана Прокоповича. Для ряда авторов-староверов данные труды служили истоком их собственных сочинений. Западноевропейские работы находили неожиданное продолжение на Руси: так был написан труд «Рассуждения о предивном величестве природы человека» С. Денисова, «Слово на святую Пятидесятницу» А. Борисова. В них использовались категории Луллия, например, «лестница субъектов». Но произведения приобретали при этом самобытный характер, создавались в свойственном Выгу стиле, восходящем к древнерусскому «плетению словес» [7].

Подобные примеры использования западноевропейских введений как основы единичны в культурной жизни Выга, старообрядчества, Русского Севера в целом. В XVIII в., когда в России торжествовало увлечение Западом, светским искусством, на Севере все же свято чтили старину, спасали ее от забвения, 
чему не препятствовало знакомство с западной культурой и ее искусное претворение в соответствии с исконной традицией последователями Аввакума.

Старообрядцы собирали древнерусские иконы и книги. Ими на Выге была создана уникальная, богатейшая библиотека. Именно здесь сохранились редкие памятники агиографии: жития Мартирия Зеленецкого, Филиппа Ирапского. Первый уставщик Выгореции Петр Прокопьев составил Четьи Минеи, опираясь на Софийский список Великих Миней Четьих митрополита Макария. Русские святые, а особенно северные, пользовались особым почитанием в обители, что отразилось, например, в иконостасе соборной часовни, где находились иконы «Зосимы и Савватия Соловецких», «Александра Свирского», «Богоматери Тихвинской», «Митрополита Филиппа», «Александра Ошевенского». Русская старина и в литературе, и в северной культуре в целом господствовала, что давало уникальные, богатейшие плоды как в искусстве, так и в науке. Отметим, что, по одной из версий, великий ученый России М.В. Ломоносов получил основы образования именно у поморских старцев-староверов [14].

По приведенным фактам жизни Выговской пустыни и на основе изучения созданных здесь произведений выявлено взаимодействие северной старообрядческой культуры и привнесенных черт, главенство при этом старины, архетипичности, стародавних канонов, которые обретали самобытное воплощение в памятниках искусства новых эпох. Народная традиция осталась на староверческом Русском Севере в век барокко, нередко являлась сильным противовесом западноевропейским влияниям, давала им необходимый яркий контраст.

Важен и недостаточно изучен вопрос взаимодействия старообрядческих центров, взаимовлияния в них художественных традиций, векторности их распространение по России. Данную научную проблему в своих трудах затрагивает, в частности, академик Н.Н. Покровский $[15,16,17]$. Малоизученным в наши дни остается воздействие Выголексинского монастыря на керженское старообрядчество. Легендарное Заволжье, поэтично и тонко описанное П.И. Мельниковым-Печерским, было связано со стародавним Севером. Безбрежные заволжские леса, спускавшиеся с холмистых берегов к водам могучей реки, переходили в вологодские. Здесь рождались произведения народных мастеров Севера, овеянные былой красой нашей исконной Руси, древней и столь современной, звучащие отголосками чудесных сказов и поверий, легенд и былей, обрядов и обычаем, бережно хранимых в старообрядческой среде.

Вернемся к художественным центрам «ревнителей древлего благочестия» в северном крае, сохранявших, интерпретировавших стародавнее искусство новгородских переселенцев в период XVIII - начала XX вв., что также позволяет судить об устойчивости древнерусских традиций в народной среде. Следует выделить староверческое село Усть-Цильму и Усть-Цилемский район современной республики Коми. О почитании культуры Великого Новгорода здесь свидетельствуют символические изображения вышивок, росписи, прошв, кружева, вязания, прядения, ткачества, росписи, резьбы. Эти традиции продолжают и ныне усть-цилемы, столь подробно и проникновенно рассказывают о происхождении орнаментов, об иносказательном смысле каждой детали праздничного многоцветья костюмов или затейливых росписей, словно продолженных в народных песнях и сказаниях старожилов. О самобытности культуры Усть-Цилемского района свидетельствует и особый художественный почерк в иконописи, который во многом созвучен выговскому иконописанию, но имеет характерное отличие использование местных красителей. Словно из самой северной земли возникали святые образы, намоленные столетиями, и сегодня сохраняющиеся в старообрядческих храмах и красных углах старинных, по-северному просторных, монументальных изб.

Древние смыслы изобразительных мотивов, как, например, интерпретация процветшего креста, значимы в старообрядческой, в том числе усть-цилемской культуре. Данное иносказательное изображение распространено в росписи, вышивке, рисованных листах Русского Севера, в частности, Выговской пустыни, района Усть-Цильма. С одной стороны, процветший крест - языческое обозначение плодородия и процветания, что менее значимо в художественно-философском восприятии образа. С другой - один из центральных символов христианства, обращение к крестным страданиям Спасителя, что уже более тысячелетия закреплено в народном сознании, неотрывно связано с крестьянским мирочувствованием, с верой и повседневностью старообрядцев. Их культура подобна та- 
кому же диковинному процветшему кресту, утвердившемуся не благодаря, а вопреки на окраинных землях, над которым не властны никакие потрясения, гонения и запреты.

Итак, автором обосновано заключение, что староверчество - уникальный социокультурный, религиозно-философский феномен, который, несмотря на позиционирование изоляции, исключительно сильно повлиял на многие духовные отечественные практики. Следует подчеркнуть исключительность старообрядчества в историко-культурной и религиозно-философской среде Севера и распространении северных традиций по России. Значима роль старообрядчества в доминировании концепта устойчивости при минимуме модернизации традиций, в определение векторности и архетипичности искусства северного края.

В исследовании впервые заключаем, что векторность - это ключевая, важнейшая дифиниция в детерминировании истоков, специфики, ареала распространения и значения староверческого северного искусства, столь значимого в масштабах отечественной и мировой культуры. Впервые предлагается спиралеобразная структура восприятия, развития и последую- щая интерпретация художественных интенций в ареале искусства Северной Руси. Радиус действия вектора, направленного от центра и охватывающего территории Поволжья, Сибири, Урала, Центральной России, значительно превосходит радиус вектора, направленного к центру из земель Москвы, Новгорода, Пскова, Ростова Великого. Отсюда вывод об исключительно высокой степени концентрации духовно-художественных традиций на северных землях, в том числе в старообрядческих центрах, что особенно значимо в определении историко-культурного, духовно-художественного статуса Севера.

Именно векторность, по выводам автора, определяет доминирование архетипичности в искусстве «ревнителей древлего благочестия» на окраинных землях. Исконные традиции не только были сохранены в произведениях искусства и повседневности последователей протопопа Аввакума, но стали культурным и духовным достоянием всего Русского Севера, всего отечественного искусства, через генетические и социальные связи нашли выражение в профессиональном творчестве, в чем первостепенно и позитивно значение векторности их культуры - исконной, общерусской, вневременной.

\section{Библиография:}

1. Примаков Е.М. Мир, в котором находится Россия. // Родная Ладога. № 3. 2012. Спб. - С. 40-53.

2. Васнецов В.М. Письма. Дневники. Воспоминания. Документы. Суждения современников. М.: Искусство, 1987. - $496 \mathrm{c}$.

3. Гончарова Л.Н. Металл в народном искусстве Русского Севера. Чеканка и медное литье. - М.: ГИМ, 2000. -95 с.

4. Суров М.В. Вологодчина: неиссякаемая дивность. - Вологда: ООО ПФ «Полиграфист», $2002 .-432$ с.

5. Мир старообрядчества. Живые традиции. Сборник научных трудов. Выпуск 4. - М.: РОССПЭН, 1998. 412 c.

6. Филиппов И. Ф. История Выговской старообрядческой пустыни. СПб.: Кожанчик, 1862. - 318 С.

7. Памятники старообрядческой письменности. - СПб.: Изд-во Русского христианского гуманитарного института, 2000. - 416 с.

8. Юхименко Е.М. Выговская старообрядческая пустынь. Духовная жизнь и литература. - Т. 1. - М.: Языки славянской культуры, 2002. - 544 с.

9. Юхименко Е.М. Выговская старообрядческая пустынь. Духовная жизнь и литература. Т. 2. - М.: Языки славянской культуры, 2002. - 480 с.

10. Павлов С.Н. Старообрядческая поморская икона: вопросы атрибуции // Программа «Храм»: сборник материалов С.-Петербургского фонда культуры. - СПб.: Храм, 1994. - С. 110-124.

11. Русское медное литье: сборник науч. статей / под ред. С.В. Гнутовой. - М.: издательство ЦМДРИ, 1993. - Вып. 1. - 191 с.

12. Русское медное литье: сборник науч. статей / под ред. С.В. Гнутовой. - М.: издательство ЦМДРИ, 1993. - Вып. 2. - 192 с.

13. Неизвестная Россия. К 300-летию Выговской старообрядческой пустыни: сборник трудов ГИМа / авторсоставитель Е.П. Винокурова [и др.] - М.: ГИМ, 1994. - 101 с. 


\section{Культура и искусство 1(31) • 2016}

14. Игумен Кирилл (Сахаров)Рецензия на книгу К.Я. Кожурина «Повседневная жизнь старообрядцев» (Москва, 2014) [Электронный ресурс]. staroobrad.ru>modules.php... (дата обращения: 28.08.2015).

15. Покровский Н.Н. «Послание В.В. к Б.И.» 1731/1732 г. - первый полемический трактат урало-сибирских староверов-софонтиевцев. [Электронный ресурc]. URL: http://www krotov.info/history/18/1730/pokrovsky. htm (дата обращения: 20.06.2015).

\section{References (transliterated):}

1. Primakov E.M. Mir, v kotorom nakhoditsya Rossiya. // Rodnaya Ladoga. № 3. 2012. Spb. - S. 40-53.

2. Vasnetsov V.M. Pis'ma. Dnevniki. Vospominaniya. Dokumenty. Suzhdeniya sovremennikov. M.: Iskusstvo, 1987. - $496 \mathrm{~s}$.

3. Goncharova L.N. Metall v narodnom iskusstve Russkogo Severa. Chekanka i mednoe lit'e. - M.: GIM, 2000. $95 \mathrm{~s}$.

4. Surov M.V. Vologodchina: neissyakaemaya divnost'. - Vologda: OOO PF «Poligrafist», 2002. - 432 s.

5. Mir staroobryadchestva. Zhivye traditsii. Sbornik nauchnykh trudov. Vypusk 4. - M.: ROSSPEN, $1998 .-412$ s.

6. Filippov I. F. Istoriya Vygovskoi staroobryadcheskoi pustyni. SPb.: Kozhanchik, 1862. - 318 S.

7. Pamyatniki staroobryadcheskoi pis'mennosti. - SPb.: Izd-vo Russkogo khristianskogo gumanitarnogo instituta, 2000. $-416 \mathrm{~s}$.

8. Yukhimenko E.M. Vygovskaya staroobryadcheskaya pustyn'. Dukhovnaya zhizn' i literatura. - T. 1. - M.: Yazyki slavyanskoi kul'tury, 2002. - 544 s.

9. Yukhimenko E.M. Vygovskaya staroobryadcheskaya pustyn'. Dukhovnaya zhizn' i literatura. T. 2. - M.: Yazyki slavyanskoi kul'tury, 2002. - $480 \mathrm{~s}$.

10. Pavlov S.N. Staroobryadcheskaya pomorskaya ikona: voprosy atributsii // Programma «Khram»: sbornik materialov S.-Peterburgskogo fonda kul'tury. - SPb.: Khram, 1994. - S. 110-124.

11. Russkoe mednoe lit'e: sbornik nauch. statei / pod red. S.V. Gnutovoi. - M.: izdatel'stvo TsMDRI, 1993. Vyp. 1. - $191 \mathrm{~s}$.

12. Russkoe mednoe lit'e: sbornik nauch. statei / pod red. S.V. Gnutovoi. - M.: izdatel'stvo TsMDRI, 1993. Vyp. 2. - $192 \mathrm{~s}$.

13. Neizvestnaya Rossiya. K 300-letiyu Vygovskoi staroobryadcheskoi pustyni: sbornik trudov GIMa / avtor-sostavitel' E.P. Vinokurova [i dr.] - M.: GIM, 1994. - 101 s.

14. Igumen Kirill (Sakharov)Retsenziya na knigu K. Ya. Kozhurina «Povsednevnaya zhizn’ staroobryadtsev» (Moskva, 2014) [Elektronnyi resurs]. staroobrad.ru>modules.php... (data obrashcheniya: 28.08.2015).

15. Pokrovskii N.N. «Poslanie V.V. k B.I.» 1731/1732 g. - pervyi polemicheskii traktat uralo-sibirskikh staroverovsofontievtsev. [Elektronnyi resurs]. URL: http://www krotov.info/history/18/1730/pokrovsky.htm (data obrashcheniya: 20.06.2015). 